\title{
USO DE PAPAÍNA EM INFECÇÕES DEVÍSCERAS*
}

\author{
Noemi Marisa Brunet Rogenski ${ }^{1}$ \\ Mércia Liberato Guedes 2 \\ Cleide Maria Caetano Baptista ${ }^{3}$ \\ Liamar Diório Ferreira Costa 4
}

\begin{abstract}
RESUMO: O trabalho foi desenvolvido no Hospital Universitário da Universidade de São Paulo e relata a experiência da utilização da papaína para irrigação de vísceras em pacientes com infecção grave. Observou-se que 72 horas após as imigações houve redução acentuada da secreção purulenta, e que o tempo médio de cicatrização total das lesões foi de 30 dias.
\end{abstract}

UNITERMOS: Papaína - Infecção dos ferimentos-Bandagens

\section{INTRODUÇÃO}

Os recursos alternativos utilzados nos mais variados campos da atividade humana têm sido consagrados por suas vantagens econômicas, por sua eficiência e por serem isentos de efeitos nocivos comuns aos fármacos e matérias primas sintéticas. A papaína é uma dessas alternativas naturais, que tem sido utilizada com grande êxito na indústria famacêutica, alimentícia e cosmética, assim como terapêutica de enfermagem, como substância indicada no tratamento de feridas infectadas e que apresentam tecido necrótico.

A literatura sobre papaina, embora ainda restrita, registra dados históricos que remontam ao curandeirismo de tribos africanas e latinoamericanas e que foram trazidos à civilização por profissionais que conviveram com esses aborígenes ${ }^{(4)}$.

A papaína (Carica papaya) é uma mistura complexa de enzimas proteolíticas e peroxidases provenientes do látex do mamoeiro, conhecido popularmente como leite de mamão (3).

Foi utilizada como cicatrizante por Starkov, em 1978, (Starkov apud MONE TTA ${ }^{4}$ ), que realizou estudos no Instituto de Aperfeiçoamento Médico do Ministério de Saúde Pública da Rússia, indicando seu uso emlesões de pele, apósobservar sua propriedade em acelerar o processo de cicatrização. Segundo FLINDT (1), a papaína age apenas no tecido lesado, devido à ausência de uma anti-protease plasmática (a alfa-um-antitripsina), que impede aação proteolítica emtecidos normais.

MONETTA $^{(4)}$ descreveu a eficiência da utilização de solução de papaína em curativos de lesões cutâneas, como úlceras de decúbito e ROGENSKI(7), em lesões provocadas pela $S$;indrome de Fournier.

Autores como Guzman e Mac Grath, citados por VELASCO ${ }^{(9)}$, afirmam que a enzima em estudo age como debridante e antinflamatório local, acelerando o processo cicatricial, sem danificar os tecidos sadios.

VELASCO ${ }^{(9)}$ faz referência a autores segundo os quais, a papaína no início desencadeia 0 aumento da secreção local, o amolecimento dos tecidos necrosados, o afrouxamento das bordas daslesõescom pequeno aumentode seu diâmetro. Após certo tempo, há o desprendimento do tecido necrosado e a diminuição rápida e gradativa do diâmetro da lesão.

MONETTA ${ }^{(4)}$, coloca como vantajoso o emprego da papaína em lesões antes de serem tratadas com antibióticos, pois essa substância facilita a limpeza da lesão, ocasionando o aumento

\footnotetext{
* Trabalho apresentado como Tema Livre no $46^{\circ}$ Congresso Brasileiro de Enfermagem. Porto Alegre, 30 de outubro a 4 de novembro de 1994.

Enfermeira Chefe da Clínica Cirúrgica do Hospital Universitário da Universidade de Săo Paulo.

Enfermeira Chefe da Unidade de Terapia Intensiva Cirúrgica do Hospital Universitário da Universidade de Såo Paulo. Enfermeira da Clínica Cirúrgica do Hospital Universitário da Universidade de Săo Paulo.

Enfermeira da Unidade de Terapia Intensiva Cirúrgica do Hospital Universitário da Universidade de Săo Paulo.
} 
da absorção do antibiótico, quando de sua utilização.

A papaína foi utilizada por via peritoneal pela primeira vez por KUBOTA(2), em estudo experimental naprevençãod eaderência peritoneal, com excelentes resultados.

Mais recentemente, STEVENS( ${ }^{(8)}$ realizou estudo semelhante, utilizando a papaína experimentalmente para prevenir a formação de aderências peritoniais, e PARRA etal. ${ }^{(5,6)}$ utilizaram a papaína como mesmo objetivo, porém, associada à carboxilmetilcelulose, concluindo que esta associação é eficaz, por prolongar o tempo de ação proteolítica da papaína.

Fundamentadas nestes estudos, as autoras deste trabalho visualizaram a possibilidade de recorrerao uso da papaína, em curativo de vísceras de pacientes com intensa produção de secreção purulenta e áreas de necrose. Os pacientes nos quais a papaína foi empregada apresentavam prognóstico altamente desfavorável e não respondiamaos tratamentos convencionais.

O objetivo deste trabalho é relatar a experiência da utilização da papaína, em quatro casos de pacientes com infecção grave em vísceras.

\section{METODOLOGIA}

O estudo foi realizado no período compreendido entre abril de 1993 e junho de 1994, no Hospital Universitário (HU) da Universidade de São Paulo, nas Unidades de Terapia Intensiva e Clínica Cinúrgica.

O trabalho será desenvolvido na forma de estudo de caso, onde serão apresentados e discutidos os casos de quatro pacientes com infecção grave em vísceras, nos quais a utilização da papaína apresentou excelentes resultados.

\section{$1^{\circ}$ caso:}

Tratava-se de paciente de 22 anos, puérpera, portadora de tuberculose pulmonar, submetida a toracotomia em hemitórax com exposição do parênquima pulmonar. Apresentava empiema e áreas de necrose nas bordas da incisão, com fístula pulmonar e perda de um segmento da costela.

A paciente foi tratada em outro serviço, sendo admitida no HU em quadro de septicemia. Após limpeza cirúrgica da cavidade, a paciente evoluiu para um quadro de choque séptico.

A cultura realizada na secreção pulmonar foi positiva para Pseudomonas aenuginosa. Embiópsia de pleura, constatou-se pleurite crônica granulomatosa, com necrose caseosa e extensa fibrose, compativel com o quadro de tuberculose.

\section{$2^{\circ}$ caso:}

Paciente de 56 anos, com diagnóstico de enfisema subcutáneo traumático com derrame pleural direito. Submetido a toracotomia com drenagem de empiema séptico em 4/3/93, 15 dias após pleurostomiae drenagem decavidade pleural. Apresentava áreas de necrose nas bordas da incisão e grande quantidade de secreção purulenta. A cultura da secreção foi positiva para Staphylococcus aureus e Citrobacter sp.

O paciente permaneceu por um periodo de um mês sendo submetido a curativos com soro fisiológico e PVPI, sem apresentar resultados satisfatórios (diminuição da secreção purulenta e início da cicatrização).

\section{$3^{\circ}$ caso:}

Paciente de 69 anos, com diagnóstico de volvo de sigmóide, submetido a laparotomia exploradora, com sigmoidectomia e colostomia. A reconstrução do trânsito intestinal foi efetuada seis meses após, evoluindo para deiscência total de parede, com fístula entérica de alto débito e grande quantidadede secreção purulenta em peritônio; foi implantada Tela de Marlex para correção da evisceração. A cultura de secreção peritoneal realizada foi positiva para Enterococcus fecalise levedura.

\section{$4^{\circ}$ caso:}

Paciente de 37 anos, portador de Síndrome de Fournier, com necrose extensa de retroperitônioà esquerda, que abrangia desde a área peri-retal até a área peri-renal, com contaminação da cavidade peritoneal.

Foram realizadas incisões amplas para drenagem do retroperitônio, desde 0 ânus até o rim, com necessidade de abertura da bolsa escrotal, e exposição testicular. As culturas realizadas foram positivas para Staphylococcus sp., Escherichia coli e Enterococcus fecalis.

Em todos os casos, os pacientes foram submetidos a antibioticoterapia específica, após antibiograma, por sete dias em média, e os curativos das lesões foram realizados com as substâncias convencionais adotadas na instituição, sem resultados satisfatórios. 
Diante do prognóstico sombrio dos pacientes e do insucesso de todas as alternativas de tratamento, as enfermeiras da clínica, que vinham utilizando há pelo menos quatro anos, a papaína em curativos cutâneos com sucesso, levaram ao grupo médico a opção de introduzir a terapia com solução de papaína nestas lesões. Inicialmente, houve resistência por parte do grupo médico em aceitar o uso deste produto. Entretanto, após várias discussões sobre os efeitos e ação da droga, deixaram a critério das enfermeiras a escolha da terapêutica ideal para os curativos em questão.

Diante disto, o grupo de enfermeiras levou aos pacientes a possibilidade de utilização de um novo recurso no tratamento de suas lesões, esclarecendo aos mesmos a forma de tratamento e a atuação da papaína.

Para iniciar a utilização da substância nos curativos destes pacientes, as enfermeiras elaboraram uma rotina específica, que foi demonstrada para os demais enfermeiros e auxiliares de enfermagem da unidade.

Ficou estabelecido que os curativos deveriam ser realizados a cada oito horas, tendo em vista a grande quantidade de secreção purulenta das lesões.

Nostrês primeiros casos foi empregada solução de papaína a $4 \%$, utilizando-se como diluente a água destilada.

A limpeza da cavidade era efetuada com auxílio de uma sonda de nelaton cuidadosamente introduzida na cavidade, através da qual irrigavase a área afetada. Após o procedimento, o paciente era posicionado para drenagem postural por aproximadamente cinco minutos, e a seguir, era efetuado curativo oclusivo da lesão.

No $3^{\circ}$ caso, o paciente possuía uma Tela de Marlexno abdômem, colocada para proporcionar maior sustentação dos tecidos. A lavagem da cavidade era efetuada seguindo o mesmo procedimento anteriormente descrito, ou seja, através de uma sonda de nelaton, que era introduzida cuidadosamente por um ponto onde a tela estava solta da pele.

No $4^{\circ}$ caso, optou-se pela utilização da solução de papaína a $2 \%$ nas primeiras 24 horas, mudandose esta concentração para $1 \%$ na continuidade do tratamento, portratar-se de irrigação contínua do peritônio, o que significaria um contato mais prolongado da víscera com a substância. Nas lesões externas, o curativo era efetuado com solução de papaína a $4 \%$, conforme procedimento padronizado na instituição para lesões cutâneas.

\section{RESULTADOS E COMENTÁRIOS}

Nos quatro casos estudados observou-se evolução semelhante, embora as lesões fossem localizadas em áreas diferentes (tórax e peritônio). Em todos os casos, houve redução acentuada da secreção, após 72 horas de introdução dos curativos com papaína, e início da formação de tecidos de granulação. O tempo médio decorrido para cicatrização total das lesões foi de 30 dias.

É importante ressaltarque, em todos os casos, o prognóstico dos pacientes era desfavorável e que não houve respesta às terapêuticas convencionais normalmente empregadas.

Nostrês primeiroscasos, a lavagem dacavidade foirealizada com solução de papaína a $4 \%$, por ser a concentração padronizada na instituição para curativos, eque vem sendo sucesso em inúmeros casos tratados pelo grupo de enfermeiros do HU (mais de 200 casos).

No $4^{\circ}$ caso, por se tratar de irrigação contínua, temia-se que, na concentração normalmente empregada (4\%), a solução pudesse provocar debridamento excessivo e, conseqüentemente, hemorragia na cavidade abdominal. Optou-se, então, com base no trabalho de VELASCO ${ }^{(9)}$, por irrigar a cavidade inicialmente com solução a $2 \%$, e posteriomente com solução a $1 \%$, pois mesmo em concentrações menores, a papaína mantém seu efeito enzimático.

Observou-se, após 48 horas de irrigação contínua, diminuição importante da quantidade da secreção purulenta sem, entretanto, ocorrência dos efeitos colaterais indesejados. Após este período, foram suspensas as irrigações contínuas e mantido apenas curativo das lesões externas com papaína a $4 \%$.

Houve cicatrização total da região afetada, após 30 dias.

\section{CONCLUSÃO}

Apesar de a amostra estudada não ser significativa (quatro casos), observou-se uma excelente resposta dos pacientes ao tratamento aplicado, principalmente na irrigação contínua com solução de papaína a $1 \%$. O grupo de enfermeiras, motivado pelos resultados obtidos, pretende ampliare aprofundar suas pesquisas, de maneira a determinar a concentração ideal para cada caso específico. 
ABSTRACT: This research was carried out at the University Hospital of the University of São Paulo and deals with the experiment of papain utilization for visceral irrigation in patients with severe infection. It was observed that seventy two hours after treatment, there was a considerable reduction of purulent secretion, and that the medium time of cicatrization of all lesions was thirty days.

KEYWORDS: Papain - Wound infection - Bandages.

\section{REFERÊNCIAS BIBLIOGRÁFICAS}

1. FLINDT, N. Health and sofety of working with enzymes. Process Biochem. London, v.13, n.8, p.3-7, 1978.

2. KUBOTA, T. The prevention of peritoneal adhesions. Japan N. Wora, v.2, p.226-29, 1992.

3. LASSOUDIERE, A. La papaine production, proprietis, utilization. Fruits. Paris, v.24, n.11/12, p.503-17, 1969.

4. MONETTA, L. A. Uso da papaína nos curativos feitos pela enfermagem. Enfoque. Săo Paulo, v.16, n.3, p.64-8, set.1988.

5. PARRA, O. M. et. al. Dose dependência da associaçăo carboximetil celulose /papaína na prevençăo de aderências peritoneais - estudo de ratos. Arq. Gastroenteral. Såo Paulo, v.28, n.3, p.99-102, jul./set. 1991.
6. Prevençăo da formaçăo de aderências peritoneais pela associaçăo de carboximetil celulose/ papaína: estudo experimental. Arq. Gastroenteral. Săo Paulo, v.28, n.2, p.63-68, abr./jun. 1991.

7. ROGENSKI, N. M. B. et. al. O uso da papaína em curativos de Síndrome de Fournier. In: Congresso Brasileiro de Enfermagem, 45, Olinda, 1993. Programa... Olinda, Associaçăo Brasileira de Enfermagem - Seçăo PE, p. $27 /$ (resumo).

8. STEVENS, L. E. A reassessment of papain in preventing peritoneal adhesion. Am. J. Surg., v.115, n.4, p.53539, apr. 1968.

9. VELASCO, M. V. R. Desenvolvimento e padronização de gel contendo papaína para uso tópico. Săo Paulo, 1993, 146p. Dissertaçăo (Mestrado) Faculdade Ciências Farmacêuticas, Universidade de Săo Paulo, 1993.

Recebido para publicaçăo em 20.12.1994.

Aprovado para publicaçăo em 13.4.1995. 